Western University

Scholarship@Western

2013

\title{
'Tis Pity She's a Realist: A Conversational Case Study in Realism and Early Modern Theater Today
}

Kim Solga

Western University, ksolga@uwo.ca

Roberta Barker

Dalhousie University

Cary Mazer

University of Pennsylvania

Follow this and additional works at: https://ir.lib.uwo.ca/englishpub

Part of the English Language and Literature Commons

Citation of this paper:

Solga, Kim; Barker, Roberta; and Mazer, Cary, "'Tis Pity She's a Realist: A Conversational Case Study in Realism and Early Modern Theater Today" (2013). Department of English Publications. 147.

https://ir.lib.uwo.ca/englishpub/147 


\title{
'Tis Pity She's a Realist: A Conversational Case Study in Realism and Early Modern Theater Today
}

\author{
ROBERTA BARKER, Dalhousie University \\ and KIM SolgA. Queen Mary University of London \\ with \\ CARY MAZER, University of Pennsylvania
}

John Ford's 'Tis Pity She's a Whore seems a particularly apt play with which to introduce an issue of Shakespeare Bulletin that explores the interaction between early modern drama and realist or naturalist performance styles on the contemporary stage. After all, for some decades now the terms "realism," "naturalism" and their cognates have frequently appeared as pejoratives when used in connection with the performance of early modern plays. Realist and naturalist theatrical approaches to the early modern canon, many scholars believe, have twisted both our understanding of these works' historical dramaturgy and our sense of their possible meanings within contemporary contexts. While such arguments have gained increasing traction within the scholarly community, they have made little impact on staging practices in the mainstream theaters of England and North America. 'Tis pity, one can hear a chorus of scholarly voices sighing, that artists still inflict realism on the masterpieces of the early modern theatrical canon.

In this collaborative essay and the issue that follows, we seek to complicate this critical narrative by reconsidering both realism's past relationships with early modern drama and its potential impact on future performances of early modern plays. The critique of realism from within theater and performance studies in general and Shakespeare studies in particular has had many salutary effects, foremost among them the manner in which it has encouraged scholars and theater artists to experiment with new ways of thinking about early modern character, acting, and performance practice. At the same time, it is often based on generalizations that demand interrogation if we are more fully to comprehend the complexities of contemporary productions of the plays of Shakespeare and his contemporaries. In this issue, we hope to show that not one monolithic realism, but many realisms, have shaped and continue to shape the ways in which early modern plays are performed and experienced on the modern stage. Where recent critics have often viewed realism as a straitjacket for contemporary artists, we suggest that it has in fact functioned more like one of those hand-me-down aristocrat's gowns that served as costumes for the boy actresses of the early modern theater. Even if it now lacks the powerful social impact of its first galvanizing appearances, it remains capable of conveying vital meanings and of appearing in different guises to a large range of spectators on the contemporary stage - as our own multivalent responses to just one production, Cheek by Jowl's 2012 'Tis Pity She 's a Whore, richly demonstrate.

In his book Realist Vision, Peter Brooks characterizes realism in the arts as a kind of "serious play." This type of play, he remarks, "uses carefully wrought and detailed toys ... that attempt as much as possible to reproduce the look and feel of the real thing" and "includes dolls that are supposed to look and act like people_characters who ought to be recognizable in terms of not only dress and appearance but also social function and, beyond that, motive, psychology" 
(3-4, our emphasis). These twin notions of reproduction of the world as it appears to the beholder's supposedly objective eye and of individual character shaped by both outward social and inward emotional forces are pivotal to realism as it has come to be understood by proponents and critics alike. Its mimetic impulses gained particular traction as nineteenth-century European and North American theaters came to focus ever more on the representation of everyday contemporary experiences and environments, especially those of the bourgeoisie that formed the majority of their audience. Meanwhile, at the height of realism's cultural influence in the late nineteenth and early twentieth centuries, it became intimately linked to-some would say, indistinguishable from - a second major movement in the period's artistic life: naturalism.

The precise relationship between realism and naturalism has been much debated by scholars: for some, "realism" describes a broad spectrum of representational strategies intended to produce an effect of verisimilitude on stage and page, while "naturalism" is a more specific intellectual and artistic movement that called upon these strategies as part of its concerted effort to depict human beings and their material environments with quasi-scientific precision (see Innes, for example). For others, the naturalists are simply "late realists" (Brooks 7) and naturalism simply a mannerist, even distracting and inefficient, version of realism. ${ }^{1}$ While debate around the meaning and value of these twinned terms continues, both realist and naturalist approaches to theater - as they were most fully articulated around the turn of the twentieth century by such dominant figures as the writers Émile Zola, Henrik Ibsen, Anton Chekhov and George Bernard Shaw, and the actor/directors Stanislavsky, André Antoine, and Harley Granville Barker - typically celebrate linear causality as the essence of narrative, depth psychology as the shaping force in characterization, and audience empathy for three-dimensional characters as the vital motor of the dramatic experience. As recent works from such celebrated television series as Denmark's The Killing and Britain's Broadchurch to Tracy Letts's Pulitzer Prize-winning play August: Osage County show, realism remains a dominant representational vocabulary in the West a full century after the time of these vanguard artists. A glance at the sets, costumes and acting styles of many recent productions of plays by Shakespeare and his contemporaries immediately demonstrates, moreover, that realism not only shapes performances of contemporary drama but also of works originally intended for historical theaters founded in quite different assumptions about acting and staging. ${ }^{2}$

Given realism's apparent vice-grip on much mainstream representation, it is inevitable that there have been skeptical takes on the form. These critiques have been crucial in their ability to encourage alternative models and critical thinking. Theater and performance artists from Vsevolod Meyerhold and Bertolt Brecht to Anne Bogart and Marina Abramovic have advanced anti-realist arguments across the span of the twentieth century, but in scholarly circles the crucial anti-realist turn arguably took place in the 1980s and 1990s. This period saw a powerful interrogation of realism's assumptions and effects by feminist critics in theater and performance studies, especially in the United States. Scholars such as Laura Mulvey, Jill Dolan, and Sue-Ellen Case all explored realism's negative implications for the feminist project. In her influential 1997 study Unmaking Mimesis, Elin Diamond effectively sums up their most important objections:

Because it naturalizes the relation between character and actor, setting and world, realism operates in concert with ideology. And because it depends on, insists on a stability of reference, an objective world that is the source and guarantor of knowledge, realism surreptitiously reinforces (even if it argues with) the arrangements of that world. (4-5) 
For Diamond et al, deeply influenced by Brecht, realism appears politically retrograde because it encourages its spectator unquestioningly to accept the stage world as natural, objectively "real" and hence unchangeable, rather than pointing up the ways in which it has been constructed by particular ideological commitments and assumptions.

A similar drive to re-emphasize the constructed status of theatrical character and setting has shaped the critique of realism from within Shakespearean and early modern studies. New Historicist and Cultural Materialist critics such as Stephen Greenblatt, Francis Barker, Catherine Belsey, and Jonathan Dollimore, among others, argued that early modern conceptions of individual personality were founded more in layers of social construction and "self-fashioning" (Greenblatt) than in any notion of constant, interiorized "character." Alan Sinfield titled a wellknown essay in his collection, Faultlines, with the question "When is a Character Not a Character?", answering that early modern playwrights often conceived theatrical characters less as psychologically complex individuals than as rhetorical devices built to fulfill ideological functions. He argued, however, that these devices nevertheless often create "character effects": illusions of "continuous or developing interiority or consciousness" that allow modern readers to endow them with a quasi-realist three-dimensionality (62).

In the wake of such work, critics such as Bridget Escolme and W. B. Worthen have expertly interrogated the continued attraction of realist illusions of interiority in contemporary Shakespearean performance. In her influential book Talking to the Audience, Escolme argues that character effects "can close down possible meanings for ... audiences, while implying that a particular version of what it is to be human - the consistent, self-contained character - should be recognised as universal" (152). Looking back to the early modern actor's tendency directly to address his audience, she suggests that contemporary theater should likewise seek vocabularies that break down the realist fourth wall separating the audience's world from the stage world and acknowledge the contingent and fictive natures of both. (For a fresh and compelling take on the manner in traditional realist methods and aims might actually work alongside non-realist methodologies to achieve such effects, see Escolme's article in this issue.) Worthen, too, asks how contemporary performance practice might move beyond realism to "respond in its own idiom to the more alienated perspective of contemporary criticism" in order to discover "a Shakespeare whose production is involved in our own deceptive and slippery rhetoric of selffashioning" (150). As the Reviews section of this issue shows, many respected theater companies of the new millennium from the Wooster Group to the Toneelgroep Amsterdam have answered this call, using their own performance idioms to articulate postmodern critical perspectives on realism and on Shakespeare.

At the same time, however, a number of performance scholars both inside and outside Shakespeare studies — including J. Ellen Gainor, Varun Begley, and Paul Yachnin — have begun to rethink realism, exploring its several dimensions as dramatic genre, as technical practice and as spectatorial currency. Although the critique of realism persists (even within some of these writers' own arguments), the rich debates in this issue around its impact on current performances show that it is is far from relinquishing its hold on the contemporary theatrical landscape, especially where Shakespeare and his contemporaries are concerned. In the context of realism's continued theatrical currency, as well as its exciting reframing (but not rejection) by a number of signal companies, continued academic resistance risks blinding us to the very important lessons realism has to teach us about contemporary performance practice; about our current, neoliberal era; and about our continued investments in the performance of, and reverence for, 400 -year-old plays. 
As we enter the second decade of the twenty-first century, we are better positioned than ever to learn these lessons. Where realism's early critics saw in it a monolithic system of representation imposing a hegemonic ideology of the "real," more recent studies have foregrounded the complexity of modern realist approaches as they have developed from a surprising variety of nineteenth- and early twentieth-century practices. The work of specialist scholars of acting such as Sharon Carnicke, Rhonda Blair and Rosemary Malague encourages us to rethink long ossified understandings of key realist ideas, including the contentious "emotion memory" and the typical elision of Stanislavsky's practice with emotional realism. ${ }^{3}$ Rather than stressing similarities, these scholars emphasize vital differences between realist dramaturgy and realist acting; between realism and naturalism; between Stanislavsky's System and Strasberg's Method; and between varying interpretations of these dominant realist approaches by such diverse practitioners as Stella Adler, Michael Chekhov, Uta Hagen, and Jerzy Grotowski, among others. ${ }^{4}$ In the process, they point the way toward a much more nuanced and productive vision of the multiple realisms that, for better or for worse, continue to offer contemporary artists a vocabulary through which to discuss and interpret early modern plays.

This issue of Shakespeare Bulletin proposes, then, that the realist survival in recent interpretations of early modern drama deserves to be taken seriously by critics, teachers, readers and lovers of Shakespeare and his contemporaries. Though realist approaches can certainly lead to ideological traps and problems (many of them explored by our contributors here), we emphasize that scholars and theater artists can acknowledge and deal with these problems from within the multivalent idiom of realism itself. We need not throw the baby out with the proverbial bathwater-especially given that, on the evidence of recent theater history, the baby refuses to be thrown out and instead is all too often left damp and shivering in the washbasin.

\section{II}

In what remains of this introductory essay, we aim to provide a working example of how scholars and artists might read a contemporary realist interpretation of an early modern tragedy critically through a lens sympathetic to the labor and flexibility of realism as technique. We take as our case study Cheek by Jowl's 2012 'Tis Pity She's A Whore, a production that, like all of this company's body of work, ably combines multiple realist praxes, especially Stanislavskyinspired rehearsal technique and Brecht-inspired stagecraft. We all saw this production live: Kim and Roberta at London's Barbican (February 2012), and Cary at the Brooklyn Academy of Music (April 2012). Further, Kim had the opportunity to view two separate archive recordings of the production at Cheek by Jowl's Barbican offices in March 2013. We base our conversation below principally on an email conversation we shared over a two-month period in 2012 .

This 'Tis Pity was resolutely "naturalist" in its set design and its use of offstage spaces, emotional realist in its acting technique, Brechtian in its placement of actors as observers on stage, highly stylized in its use of sound, lighting, dance, and blocking, and "in-yer-face" in its depictions of on and offstage violence (see Sierz). Set in teenage Annabella's blood-red bedroom - complete with to-the-minute TV and film posters, laptop computer, portable CD player, makeup, messy closet, and high-street trappings - the 2012 show $^{5}$ opened with Lydia Wilson's Annabella lolling on her bed, the only major item of furniture in the space, "hanging out" while the audience filed in. As the house lights dimmed, she set on a disc and pounding club music filled the theater. Moving powerfully yet seductively on top of the bed, the dance already in her body, Wilson was in full control of the stage space as the cast entered one by one to dance 
to her choreographed beats. This charged opening grabbed spectators' attentions, literally aligning our heartbeats with the cast's pulsations; Wilson's fierce middle distance gaze created a mediatized effect, making us feel the urgency and the exhilaration of her made-for-MTV spectacle. When the music cut, Giovanni and the Friar broke sharply from the chorus line to launch straight into their opening exchange. Meanwhile, the rest of the cast settled onto Annabella's bed with Wilson to watch intently. This moment captured the aesthetic of the whole show.

At the same time as this opening sequence both articulated and undermined the realistic contemporary setting, however, the performers followed clearly marked emotional trajectories most spectators will have found familiar. Wilson's Annabella felt her power, encountered her desire, assimilated her social reality, and both resisted and accepted her fate as the play moved toward its brutal conclusion. Giovanni moved from childish self-deception to heartbreaking neediness to full-blown mental illness. Soranzo discovered frailty, love and deep rage as he adored Annabella, beat her pregnant body, and plotted Giovanni's death. Each central performer's emotional trajectory resonated for us and dictated what we liked and did not like about the production. Similarly, characters whose through-lines were not clear represented for us flaws in the show's fabric, since those who did achieve such clarity shaped our sense of its artistic goals.

Yet our reactions to the production are not determined exclusively by the "believability" of character trajectories, but rather by the ways in which the production's several realismsmultiply constituted, differentially invested, and staged sometimes in concert and sometimes in tension one with another-interwove to form a broader sociopolitical commentary about gender, power and violence in the early twenty-first century. We now rehearse our reflections upon these intersecting themes by restaging our post-show email conversation, structuring our polylogue around the interactions among the production's set design, its acting and directing techniques, and the sometimes contradictory significations its emotional realist labor created for us as individual audience members.

\section{Space, privacy, visibility}

\section{CARY}

Hi Roberta and Kim,

I saw 'Tis Pity yesterday in Brooklyn, and loved it. The company clearly chose to delete elements of the text that can function as distractions from the central plot featuring Annabella and Giovanni; this is also, of course, a strategy that shapes the production as much more modern, linear social realism than sprawling early modern tragedy.

That said, I was dying of curiosity about how you both reacted to the bed as a continual presence on stage, front-and-center. The use of a focus like that doesn't strike me as unusual for Declan Donnellan and Nick Ormerod, who are often very stylized in their use of design elements, but having the bed operate as a real object in a functioning bedroom with walls and decor and lots of other everyday items around it was something I hadn't seem them do before. The bed's "realistic" presence seemed especially remarkable given that they continued their typical, antirealist practice of using off-stage characters as onstage individual and group presences/observers, especially on and around the bed.

I'm interested in the bed not just as a director-driven theatrical sign (which it no doubt is), but as a practical, "coaching" device to help focus an actor's energies, which then yields a potent 
theatrical sign. Can we read the bed as first and foremost a function of the company's emotional realist rehearsal technique, and subsequently as a means of audience engagement with the themes, ideas, and questions with which the company is wrestling?

For example, I can imagine the bed functioning as a "target" in Donnellan's sense of the term. What I like about Donnellan's notion of the "target" is that it allows him to retain Stanislavsky's focus on emotional action without allowing the actors to get hung up in Strasbergian introspection. In Donnellan's praxis the actor does not play an objective that comes out of herself, but plays in relation to a moving target outside of herself that is changing from moment to moment, and to which she has an unstable, even contradictory relationship. The actor thus does not try to become her character, but to see the world, the situation and the other characters in the play through her character's eyes (see Target 16-29, esp 22-25, and 46-48). ${ }^{6}$ Might not the bed have originated as a material way of provoking the cast to develop their characters in relation to the space and objects around them, and in particular to assist Lydia Wilson in framing Annabella's interactions with the characters (Giovanni, Soranzo and Vasques, among others) who are constantly placed around the bed but not always figured as "onstage" with her? I don't have an answer to this question yet, but instead of reading its "meaning" I'm trying to link the physical concreteness of the bed with what might have been a series of discoveries about character and circumstance in rehearsal.

\section{KIM}

One of the things I appreciate about Donnellan's "target" is its Brechtian affinities. Donnellan is influenced by Stanislavsky in his rehearsal technique, yet he's also very clear that the target is not an objective or a super-objective (27): rather, it is active, transformative, and changeable (47). In the spirit of this conscious blending of emotional and social realisms, I find it exciting and productive to imagine Annabella's bed as a kind of naturalistic materialization of Brecht's "not/but": not just an actor's tool to find character, establish relationships, and negotiate her role onstage, but also as a means of establishing, reading, and mobilizing the production's larger power dynamics. The bed is easily the most important, consistent site of power play on stage, and it radiates the shifting vectors of familial, gendered and social control at the heart of Ford's text through the space. [Insert Fig.1]

Annabella treats the bed as her personal fiefdom, but she is also very much a child: she makes her opening power-play with the dance number but then naively acts, in the next scene, as though the bed is a space of ultimate safety. (One moment that stays with me is that where, as Giovanni tells the Friar of his love/lust for his sister, she plays with sock puppets, giggles and eventually does an effortless handstand in the middle of the bouncy mattress). As a site of power the bed is "up for grabs" throughout the show, and Annabella's own relationship to it is contradictory: gradually yet not fully knowingly, she loses control over the bed until Giovanni snaps her neck while kneeling with her on it. Annabella also shifts her own relationship to the bed over time, as Wilson tracks changes in her character's perceptions of the world around her by changing the way Annabella inhabits the bed as "her" space.

I wonder if we might also bring the production's other key spatial marker - the working bathroom upstage left - into our discussion at this point. I'm really interested in the way Ormerod's design played with the notion of a fourth wall: our gaze is directed into the most intimate of spaces (a young woman's bedroom); there is a room at the back, stage right, that appears to be a common area and that lets us see part of the wedding party, and then there's a functioning bath on the opposite side, complete with working shower, sink and toilet (the latter 
of which we cannot see). Both "half-stage" spaces are fully naturalistic in the sense that August Strindberg and André Antoine intended at the end of the nineteenth century ${ }^{7}$ and together they map a distinct trajectory both through the play (semiotically) and across the stage space (psychophysically) for audiences and actors. Moving stage right to left, the space shifts from modestly public to extremely private (and dangerously so: the bathroom is the site of gruesome violence, especially by Soranzo and Giovanni on Annabella). This theatrical topography is deeply indebted to the logic of naturalism: it invites a certain level of voyeurism from audiences, which worries me, but as it calls deliberate attention to its own erasures it also demands a high level of creative — and, I think, ethical—engagement from viewers left to fill in gaps on our own.

\section{CARY}

What I loved most about the bathroom was its deliberate partial visibility. In her work on Miss Julie, Una Chaudhuri correlates the use of space in the naturalist project with questions of visibility and privacy, and she explores Strindberg's set for Miss Julie as evidence not of the "total visibility" (27) naturalism seems to want to achieve, but of the limits of visibility (35). She thinks about the set in terms of its articulations of private and public, safe and unsafe spaces. ${ }^{8}$

Might something like that be happening here? The bathroom is a semi-visible, inner space for private acts such as douching (Putana is so matter of fact about this), excreting (we hear the toilet flush a couple of times), showering and bodily maintenance (by both men and women). It is also the place where Giovanni, with the door closed, dismembers Annabella's body, the sound of the chainsaw as raw and disturbing as anything we might see with our own eyes. Giovanni (among others) wants to see inside Annabella's body; that is the conceit that powers the entire play, if not early modern tragedy in general. And the bathroom's naturalistic semitransparency, especially as he hacks up her body, articulates beautifully the mad futility of that (entirely naturalistic) ambition.

\section{ROBERTA}

In the case of the bathroom in particular, I think Cheek by Jowl achieves an exciting fusion of early modern, nineteenth-century naturalistic and contemporary cinematic notions about spatiality. The bathroom is the early modern discovery space in which fascinating secrets, beautiful tableaux and horrific violence can all be disclosed. It is Chaudhuri's Strindbergian halfoffstage space, straining both with and against naturalism's longing for full disclosure. But it is also the haunting, even slightly uncanny space that lurks just outside the camera's frame in films such as Polanski's Rosemary's Baby or Lynch's Mulholland Drive: the space that the denizens of an apparently workaday bourgeois world can barely glimpse in their peripheral vision but that turns out to be the home of hidden terrors that transform that world forever. And this mingling of a contemporary filmic vocabulary into the theatrical vocabularies of the production takes us to another crucial aspect of the space.

The back wall of Annabella's bedroom is adorned with a set of film posters: True Blood, Gone with the Wind, Breakfast at Tiffany's. All of them evoke representations of women being swept off their feet, objectified, seduced, even destroyed. Presumably Donnellan and Ormerod (very likely with actors' input) chose these posters to suggest Annabella's own preferences_-and very teen-realist they were, too. But do her chosen images, in which women are precisely not in power, exist in tension with the presence of the bed in front of them - that is, with Annabella's clear sense of owning her domain? For me, the posters have to be taken as a part of Annabella's process of wrestling with identity. They function as signs in the language of the contemporary 
Imaginary that allow young women like her to imagine empowered selves into being, but that also limit that process of imagination by shaping its terms in advance in ways that constrain the possibilities young women can inhabit. In a sense, with those posters on the wall we should know from the start that the bed is always going to turn out to be a deathbed, and the bathroom the site of the shower scene from Psycho.

\section{KIM}

Perhaps, via those posters, Annabella's bed becomes the production's feminist vanishing point. After all, the world into which we all plunge when Annabella brings her music up and the cast dances on is framed by her habitation of the bed plus all the worldly stuff around it plus the dreamscape the posters paint. This set-up is at once clearly impressionistic (we are inside Annabella's imagined universe, blood red, strong and loud) and yet also fully, objectively materialized - though not in an especially progressive or even feminist way (the voyeurism about which I worry in the production is embodied by the prominent True Blood poster, with its sexy, woman's licking lips). The bed is the space where these two frames of reference - and their competing notions of what it means to be/become a woman-collide.

To return to the language of targets, I suspect the posters functioned not just for spectators to "make sense" of Annabella, but also for Wilson as a series of lenses through which she could see Annabella conceiving and arranging her world as inherently but blissfully contradictory, populated by strong chicks and girly-girls at one and the same time. Annabella lives in an imagination where all identities are possible simultaneously... but then her father's real world, with its rigorous insistence on bolting women down, presses in. This set-up reminds me, too, of the Stanislavskian principle that all character work is ultimately about imagination: that "experiencing" on stage is a process of imaginative living in constantly shifting relation to the given circumstances of the text (see Carnicke 109-23). Perhaps, then, the naturalistic physicality at work in this production - from the "stuff" in the bedroom to the flushing toilet to the terrifyingly real violence visited on each of the women-depends overtly, perhaps even selfconsciously, on the working-through of imagination as both realist praxis and feminist theme. How might an actor or an audience member imagine herself into Annabella's position? How might Annabella herself imagine — and in imagining, affect - that position?

\section{Acting and imagining}

\section{CARY}

On that note, I was wondering how you each thought Annabella tracked psychologically: how she got from her doubling down on Giovanni's confession of love and her flagrant defiance of Soranzo in confessing her pregnancy on her wedding night to the point of repenting her affair with Giovanni, acceding to the Priest's cosmology and reconciling with Soranzo. There's so much by-play with a shopping bag of baby clothes that Soranzo brings her toward the end; we see her considering and playing with these tiny objects (targets, again?) and appearing to begin to imagine herself differently as she does so. Is it just the pregnancy that spurs her to change her mind? (That seems too easy and obvious.)

\section{ROBERTA}

I was never sure whether we were meant to receive the action of the play as happening objectively or as taking place completely within Annabella's head, in the realm of her fantasy. 
Even if it did happen objectively, the action was clearly shaped by Annabella's imagination, rather than by Giovanni's; her wishes, her choices, drove the action much more than his did. I took the resulting trajectory as a reflection on the kind of contemporary constructions of female desire we see in films like those represented by her posters: Twilight, True Blood, and so on. The heroines of these works tacitly proclaim that they have the right to desire-even to desire the teeth that bite them. In this light, I thought Annabella's journey was in part a shift from finding pleasure in a fantasy of Giovanni as Edward in Twilight (the demon lover) to focusing upon a (perhaps) more mature vision of Soranzo as a potential father and life-partner. Similarly, she began to fantasize herself as a mother rather than as a sexy, self-destructive, rebellious Bella figure.

\section{CARY}

While watching, it never crossed my mind that we were seeing the play from Annabella's point of view, but it makes perfect sense to read the production that way. She is onstage through the warmers, and Putana's discussion of the suitors is staged as a comic show-and-tell with Annabella as wry-looking audience member. I may not have spotted this angle because I was generally overwhelmed by the male power constantly circling the bed; I wouldn't have thought she'd choose to populate her imagined world with menacing, often shadowy men continuously watching her.

\section{KIM}

On my first viewing, I sensed that Annabella was blithely oblivious to all those men wanting to devour or destroy her. I read her as growing up by learning to recognize them: Wilson's arc was for me one of coming into knowledge about the real world beyond Annabella's bed/her head, the world in which she actually lives and needs to survive. This explained the arrival of the baby clothes, as well as the shift in Wilson's physical relationship to the bed that I mentioned earlier. After she decided to be with Soranzo and not Giovanni, she more often sat quietly on or in front of the bed rather than flailing boisterously across it. She began to behave like a young adult-in fact, like a young "lady," for better or for worse - minimizing her childish physicality if not leaving it behind entirely.

\section{ROBERTA}

I think of Annabella's relationship to fantasy in the psychoanalytic sense, specifically in terms of Melanie Klein's understanding of "phantasy" as a kind of inward play activity through which the child "tests out, primitively 'thinks' about, its experiences of inside and outside" (Klein 23).

Klein argues that these "phantasies" are often extremely violent, aggressive and even painful or traumatic. I prefer to read the whole show as happening in Annabella's psyche and as externalizing that very coming into knowledge about the world in which she lives that Kim describes. For me the production seemed an exploration of the psychic life of a smart, strong, creative young woman whose strong will and emerging sexuality develop within a culture that gives women a certain surface "freedom" but is still crammed with powerful, residual patriarchal takes on femininity. Annabella is objectified, ogled by those men around her bed. She is fetishized, at one point even participating in her suitors' staging of her as the Blessed Virgin Mary complete with veil and halo. And she is demonized, as when Soranzo pictures her as a lubricious whore during the sexual play that begins the "wedding night" scene. These are her 
options, and all of them affect how she, as well as the men around her, think, act and react.

\section{[Insert Fig.2]}

Like Kim, I see Annabella struggling to master and dominate the world around her, but for me this was more a struggle with psychic forces that included her own desires. Hence we began in her head (with the choreographed dance), and ended in her head, as she returned in the show's final moment to clamber across the bed and reach between Giovanni's hands toward her own (dying) heart. I understood this final, haunting image as a representation of Annabella's psyche coming, as if in dream/ nightmare, to visit the phantasy of her own and her closest family members' destruction. The bed WAS her head, in this sense: the stage on which her conscious and unconscious working-through of all of her questions about who she was, and who she might become, took place.

\section{KIM}

Klein is a superb thinker through whom to understand Annabella as a child coming into womanhood, but at this juncture I find myself returning to the challenge of playing that trajectory, and thereby to the power of imagination in Stanislavskian theory and praxis. For Stanislavsky, the work of an actor's imagination lies at the core of the System; it is the key that not only unlocks the given circumstances, but also enables the "doubleness" of an actor's work on character, in which the actor maintains a sense of persona as character while simultaneously looking at the character from a modest distance in order to maintain a larger sense of the play's action. In Stanislavsky's writings, as also in Donnellan's, the labor of emotional realism is conceived not as "living" the role so much as living in and through the imagined situation in which a character finds him or herself. One needs to see as the character, but more importantlyand at the same time - one needs to see as the actor and through the character, a double optic that involves keeping two (competing, yet also collaborating) realities in view at any one time (Stanislavski 456-62). At its best this kind of emotional realism is a profoundly other-centered kind of work, perhaps even a kind of curative for the destructive fantasies that can trap us all in our own heads.

When I think about Wilson's Annabella at the top of this show, I remember a figure engulfed by the phantasmatic image of herself as powerful, strong, in control over her world and its inhabitants; like a misguided Method actor she saw herself as the only figure in the space whose desires mattered, and she regarded herself (dangerously) as self sufficient. The moment she came to realize that a good, even happy, future with Soranzo might be possible was for me the moment she recognized, perhaps for the first time, what another human being felt for her. This moment occurred after she had confessed her pregnancy to Soranzo by holding his hands against her belly during the post-wedding scene (4.3), and Wilson communicated Annabella's recognition clearly, a profound look of surprise on her face as she said, "I must confess, I know you loved me well" (4.3.120). Not long after, she delivered her 5.1 soliloquy sitting cross-legged before (significantly, not on) the bed; the speech was parsed out cautiously, punctuated by eye contact with the audience and by a rhythmic delivery Wilson had cultivated throughout to suggest Annabella's thought processes. The soliloquy did not sound like contrition to me, but like learning: we were watching Annabella thinking in real time, reading the situation, making choices; she was having a reasoned conversation with herself and with us about what was happening to her, and about what she was going to do about it.

I was really moved by this moment in performance; it was as though Wilson was offering us the fruits of her own rehearsal process by playing out Annabella's process as a young woman 
grappling with her own very difficult set of given circumstances. When she then moved from this scene into an embrace with Soranzo and the baby clothes he proffered, Annabella appeared to choose "life" in the richest sense of the term, instead of carrying on with Giovanni along the path to self-destruction. Despite the fact that it risks reinforcing maternity as essential to women's maturity, I would argue that within the limiting contexts provided by the play this is a potentially feminist, if troubled, reading of the character. [Insert Fig.3]

\section{Psycho-physical realities}

\section{ROBERTA}

We've entered murky waters here. When we speak of Wilson's Annabella-and the production itself — as advancing a feminist reading, we need to keep in mind that Wilson spent a great deal of her time in this show not only lounging in her bedroom, but lounging in a rather sexy-looking camisole and knickers. Was this simply what she wore for pleasure, even for comfort, in her private world? Or was there a sense in which this costuming opened her to the sexual fantasies of the men around her, and perhaps of the audience, too? My mother, a strong second-wave feminist who saw the production with me, certainly read Annabella's "look" in this way and emphatically disapproved. Though her performance was so gloriously forceful, when dressed in this costume Wilson's physique - youthful to the point of childishness, very slender, and to my mother's eyes perfectly in line with many of the female bodies we see on models in lingerie ads and in fashion magazines - permitted a reading of her Annabella as a kind of millennial Lolita figure. She arguably remained appropriable for a discourse of femininity as infantilized, nubile and objectified.

\section{KIM}

I found Wilson to be young, without question, but not model-esque; I was entranced by her muscular body and its elegant, dissonant movements (she pirouetted perfectly one moment, jerkily kicked and fought the next). The way she moved was rarely "beautiful" in a conventional way; it was athletic, and in that habitation her body challenged the outward show of fetishized feminine stereotype her costume projected. In her freedom of movement she embodied for me something of the strength and force many women guard beneath the veneer of sanctioned femininity; she was figured on the cusp of adulthood - she had a woman's body, but had not yet learned to be demure. Her constantly evolving, often-antagonistic physical presence felt exhilarating to me through the first three quarters of the show, but ultimately it slipped into a noteasily-comprehensible sense of loss as I watched her reappear, defeated (?), in the final moments, approach the bed and stretch toward her heart. This last gesture was forward-looking. Her gaze one of curiosity and wonder, and fear and mourning; she seemed to be at once looking into the future and realizing the future was gone. She left me, as a feminist spectator, uncertain what to feel.

\section{CARY}

The tendency to psychologize early modern heroines often leads, in contemporary emotionalrealist stagings, to psychopathologizing. But the odd thing is that, by giving Annabella such a strong physical presence, this production ended up psychopathologizing Giovanni! I'm glad that Cheek by Jowl shifted the focus from him to her, but there was an expensive trade-off: by the last scene Giovanni became - to use the term you invoked for the bathroom, Roberta-literally 
"psycho." Of course, in modern productions Giovanni is frequently portrayed as mad by the end, ${ }^{9}$ but given both how physically dominant and how emotionally complex Wilson's Annabella was, Jack Gordon's Giovanni appeared by contrast transparently crazy, walking out of the bathroom slick with blood and gore, staring manically at the heart in his hands. It was the only thing he wanted to possess about his sister, and now it was the only thing he could possess.

\section{KIM}

You're right, Cary: it seems the price of a challenging, multifaceted Annabella was a comparatively flat Giovanni. His obsessive tendencies were clear to me from his first interactions with the Friar, and rendered him a petulant, irritating child — but his childishness did not work for me the way Annabella's did. Giovanni seemed always to be playing Annabella's plaything, slightly older but less mature: for example, as she surveyed the room with Putana in 2.1 she sat on the bed, in charge of the scene, while he lay belly-up in front of it, reading, like a child engrossed in a comic book. Similarly, during the wedding scene, he wandered among the guests with a camcorder, a creepy, self-involved teen, and she rebuked him subtly. His actions served as Annabella's continual foil; Gordon's labor thus helped enable the complexity we can read in Wilson's Annabella. Meanwhile, he felt one-dimensional.

\section{ROBERTA}

I often find that when productions have a "feminist" thesis, the result is more careful thinking about female than male characters, which I think can be very unfortunate if it implies that only women are implicated in gender politics and struggle in complex ways. In this case, Annabella was so clearly a figure working (like the actor who played her) imaginatively to transform her targets, while many of them men remained trapped in stances that never quite achieved an aura of either deliberate stylization or critical force.

\section{KIM}

The exception to this problem for me was Laurence Spellman's Vasques, whotracing the show's cinematic echoes - seemed torn straight from Lock, Stock and Two Smoking Barrels, a charming killer who was both ambiguous in motive and exceptional at modulating his social performance according to context. I never saw who he really was, though he offered me a clear picture of a man conflicted by his job, a bit anxious about its mounting collateral damage, yet okay, if not exactly happy, to carry on doing it. For me, that's a model of strong emotional realist work: he offered no answers, but hinted at multiple possible ways of understanding his behavior under the circumstances.

\section{CARY}

There is a useful challenge implicit in Roberta's phrase: "when productions have a 'feminist' thesis." What interests the three of us is how contemporary theater artists who refuse to accept the "realism is conservative because it reifies the status quo" argument instead use the tools of emotional, psychological, and/or biographical realism in the service of a (in this case, feminist) political agenda. And what is key, I sense, to the viability of this approach is a strategy of emotionalizing without psychopathologizing. Otherwise, you get women who are crippled by patriarchy and rendered as sick and vicious as the men (like many versions of Middleton and Rowley's Beatrice-Joanna), or women who are figured as saintly martyrs (like the Victorian take on the Duchess of Malfi), often because the men in the play are framed as lunatics-which 
avoids psychopathologizing the women, but, as they say about the devil in nineteenth-century Faust operas, gives the men all the best tunes. Or there's the option in which women may be independent, powerful, capable not only of autonomy and sexuality but also of their own journey and character arc ... but the men are still more interesting because they are "psycho." I think the latter is why I had problems with this Giovanni, as well as with Annabella's baby clothes: male playwrights, male directors, and even liberal but not radical female playwrights, when they need to flesh out female characters, seem not to be able to come up with much beyond fertility.

\section{ROBERTA}

The most exciting and successful productions of early modern tragedy that I've seen remain those that really interrogate both men's and women's roles, and that start from the assumption that both women and men can collude in gender oppression as well as suffer from it. Surely this sense of the complexity of gendered experience was one of the key insights of Ibsen's own work! An exploration of the fraught ways in which both "oppressed" and "oppressor" suffer from, and strive to transform, the very oppressive structures in which they nevertheless participate is something the realist heritage can offer to the project of bringing socio-political nuance to the performance of early modern plays today.

In that regard, I thought the final moments of extreme violence and its aftermath were among this production's most effective. As Giovanni struggled with Annabella on and around the bed; as she proclaimed her final allegiance to Soranzo; as Giovanni snapped her neck, cradled her body and hauled her into the bathroom, chainsaw at his side; and especially as the whole cast reacted with horror and nausea at the sight of that clinically white bathroom spattered from floor to ceiling with her blood, we really got a strong sense of the costs of this production's social order, or perhaps of this fantasy of a social order, for everyone involved.

\section{KIM}

I had two strong, contradictory reactions to the ending. I was gut-wrenched alongside the male characters as I watched each of them bear witness at the bathroom door, reacting so viscerally to whatever was inside (which we could not see directly). I also felt a strong surge of anger at their audacity in making this event so intensely about them, and at their tacit request that I feel for, or even with, them now. Their willful blindness had borne this fruit; now that Annabella was gone, her (death)bed taken over by retching, puking boys, how dare they ask me to transfer my allegiance, my empathy - to forget all that she had gone through? When Wilson returned, stepping with uncharacteristic tentativeness from the stage right wings, I felt relief alongside that nagging but nebulous sense of loss I mentioned earlier, yet also some confusion. Where were we now? Who was she now? And what did this return mean? [Insert Fig.4]

\section{ROBERTA}

I think that confusion was a vital part of this production's affect. It was powerful enough to provoke many possible meanings, but perhaps we are realizing that it was also incoherent enough to provoke too many possible meanings. The ending invited Kim's view of Annabella as a powerful - if finally doomed - transformative force in her world, but it could also easily allow a viewer to fix Annabella simply as a victim, the archetypal "lost girl" rendered pure object at last. Cheek by Jowl's fondness for tension, contradiction and the juxtaposition of contrary elements and styles ("Brecht" alongside "Stanislavsky") is precisely what makes the company's work exciting and provocative, but it also opens its signifiers to some very retrograde readings. 
On the other hand, such a level of uncertainty and risk poses a helpful challenge to the Brechtianinfluenced critique that tells us that emotional realism is simply too linear, too smooth, to incite debate.

\section{KIM}

Theater that deals provocatively and complexly with, and in, affect, as emotional realism does, always risks the possibility that some audience members will react without reading the nuances. We definitely need as academic critics to remember that a performance's impact is only as strong as its spectators' engagements with it — but also that those engagements are often surprisingly sophisticated! At their best, emotional realist techniques offer contemporary theater workers a means to be political without "Being Political": a way to put an affectively rich, multifaceted social politic on the stage, leaving audiences to work with intersecting, not always clear, character trajectories, and to come to their own conclusions about who does what, why, and what it could or should mean. In an age when much overtly "political" art risks being either defunded by government agencies or co-opted as "safe" for neoliberal boosterism, carefully wrought realist praxis that is not afraid to risk uncertainty and embed competing emotional and intellectual trajectories can be a helpful, inclusive strategy for encouraging politically sophisticated thinking in a wide cross section of audiences.

\section{III}

As we hope our multivalent responses to this single production have suggested, the realisms (and naturalisms) with which this issue engages do not enforce a pre-determined consideration of space, subjectivity, the body or its meanings in performance so much as enable a range of perspectives on the "real" from within parameters set by individual productions. The papers that follow offer multiple and often conflicting definitions of both "realism" and "naturalism" as they apply to the performance of early modern drama on today's stages, and they examine not only the familiar works of Shakespeare but also the less frequently staged plays of dramatists such as Thomas Heywood, Thomas Dekker, William Rowley, and John Ford. They consider how multiple ways of looking through the realist lens can expose its cracks, limitations, and blind spots, but they also demonstrate the extent to which the old lens can still offers us fresh and unsettling perspectives on early modern plays. Most significantly, they all challenge the simple binaries that have sometimes marked the relationship between realism and early modern theater and performance.

Paul Prescott begins the issue by rethinking the career of Sam Wanamaker, the celebrated founding father of the reconstructed Globe Theatre and its "original practices" mandate. He reminds us that as a young Shakespearean actor Wanamaker fervently espoused a version of "Method" acting that had tremendous — even subversive - political and social significance for his peers, and further demonstrates how Wanamaker's thinking and practice built upon the work of both Stanislavsky and Bertolt Brecht, two thinkers often seen as the opposite poles of a modern theatrical spectrum. Prescott's essay thus lays the foundation for Bridget Escolme's "Putting it on the Floor," in which she too rethinks the Stanislavsky/Brecht binary, exploring how the juxtaposition of realist acting and non-realist scenography in contemporary rehearsal and performance practice can work to achieve effects both emotionally moving and politically powerful when applied to early modern playtexts.. 
A pair of essays by M.J. Kidnie and Rosemary Malague examining Katie Mitchell's 2011 production of Heywood's A Woman Killed with Kindness confirm Escolme's sense that the encounter between realism and early modern drama can be both refreshing and politically potent. Kidnie considers Mitchell's production — with its elaborate naturalistic setting in 1919 — as a radical feminist adaptation of Heywood's 1603 playtext, while Malague focuses upon the rehearsal and performance strategies through which the bodies of Mitchell's actors worked to grant visibility to the suffering of Heywood's women. Though they take complementary approaches and come to differing conclusions about the success of Mitchell's project, both authors challenge any easy binary between realist praxis and feminist commitment.

Brett Gamboa's essay on the sources of the "real" in Shakespearean performance follows the spirit of Kidnie and Malague's critical dialogue as it interrogates clear distinctions between artists and audiences as makers of theatrical meaning. Questioning the notion that a sense of reality onstage proceeds only from the choices and techniques of actors and directors, he argues that spectators are the prime agents of the theatrical "real," and that their ability to find it in a representation can sometimes be enhanced, rather than harmed, by failures of strict theatrical realism. Finally, Tom Cornford concludes by looking back at the complex original encounter between Shakespeare and Stanislavsky. He shows how that encounter ruptured a simple opposition between process and product for Stanislavsky, as Shakespeare came to embody for him the spirit of experiment and exploration on which he based his open, playful and questioning Studio practice. Elegantly gathering together the issue's several foregoing strands, Cornford ably articulates its central vision of multiple realisms as forces not of stasis, but of provocative, sometimes revolutionary theatrical change.

\section{WORKS CITED}

Barker, Francis. The Tremulous Private Body: Essays on Subjection. Ann Arbor: University of Michigan P, 1995. Print.

Barker, Roberta. “'A freshly creepy reality”: Jacobean Tragedy and Realist Acting on the Contemporary Stage.” Performing Early Modern Drama Today. Ed. Pascale Aebischer and Kathryn Prince. Cambridge: CUP, 2012. 121-41. Print.

-----. "Inner Monologues: Realist Acting and/as Shakespearian Performance Text." Shakespeare Survey 62 (2009): 249-60. Web.

Begley, Varun. "Objects of Realism: Bertolt Brecht, Roland Barthes, and Marsha Norman." TJ 64 (2012): 337-53. Web.

Belsey, Catherine. The Subject of Tragedy: Identity and Difference in Renaissance Drama. London and New York: Methuen, 1985. Print.

Blair, Rhonda. "Reconsidering Stanislavsky: Feeling, Feminism, and the Actor." Theatre Topics 12.2 (2002): 177-190. Print.

Brooks, Peter. Realist Vision. New Haven and London: Yale UP, 2005. Print. 
Carnicke, Sharon. Stanislavsky in Focus: An Acting Master for the Twenty-First Century. $2^{\text {nd }}$ ed. London and New York: Routledge, 2008. Print.

Case, Sue Ellen. Feminism and Theatre. 1988. Reissued ed. Basingstoke: Palgrave, 2008. Print. Chaudhuri, Una. Staging Place: The Geography of Modern Drama. Ann Arbor: University of Michigan P, 1995. Print.

Diamond, Elin. Unmaking Mimesis: Essays in Feminism and Theater. London and New York: Routledge, 1997. Print.

Dolan, Jill. The Feminist Spectator as Critic. Ann Arbor: University of Michigan P, 1988. Print.

Dollimore, Jonathan. Radical Tragedy: Religion, Ideology, and Power in the Drama of Shakespeare and his Contemporaries. Chicago: University of Chicago P, 1984. Print.

Donnellan, Declan. The Actor and the Target. London: Nick Hern, 2005. Print.

Escolme, Bridget. Talking to the Audience: Shakespeare, Performance, Self. London and New York: Routledge, 2005. Print.

Fortes, Edward. Personal email to Kim Solga. 21 June 2013. Email.

Gainor, J. Ellen. "Rethinking Feminism, Stanislavsky, and Performance." Theatre Topics 12.2 (2002): 163-75. Print.

Gordon, Robert. The Purpose of Playing: Modern Acting Theories in Perspective (Ann Arbor: U of Michigan Press, 2006. Print.

Greenblatt, Stephen. Renaissance Self-Fashioning: From More to Shakespeare. Chicago and London: University of Chicago Press, 1980. Print.

Innes, Christopher, ed. A Sourcebook on Naturalist Theatre. London and New York: Routledge, 2000. Print,

Klein, Melanie. The Selected Melanie Klein. Ed. Juliet Mitchell. New York: Free Press, 1987. Print.

Malague, Rosemary. An Actress Prepares: Women and "The Method". London and New York: Routledge, 2012. Print.

Mulvey, Laura. "Visual Pleasure and Narrative Cinema.” Screen 16.3 (1975): 6-18. Web.

Sierz, Aleks. In-Yer-Face Theater: British Drama Today. London: Faber, 2001. Print. 
Sinfield, Alan. Faultlines: Cultural Materialism and the Politics of Dissident Reading. Oxford: Clarendon Press, 1992. Print.

Solga, Kim. "Realism and the Ethics of Risk at the Stratford Shakespeare Festival." Shakespeare Bulletin 28.4 (Winter 2010): 417-42. Web.

Stanislavsky, Konstantin. An Actor's Work: A Student's Diary. Trans. Jean Benedetti. London and New York: Routledge, 2008. Print.

Strindberg, August. "Preface to Miss Julie." Miss Julie and Other Plays. Oxford: Oxford UP, 2009. 55-68. Print.

'Tis Pity She's a Whore. By John Ford. Dir. Declan Donnellan. Design Nick Ormerod. Cheek by Jowl at the Barbican Centre, London, and the Brooklyn Academy of Music, New York. 2012. Performance.

Williams, Kirk. "Anti-Theatricality and the Limits of Naturalism." Against Theater: Creative Destructions on the Modernist Stage. Ed. Alan Ackerman and Martin Puchner.New York: Palgrave, 2007. 95-111. Print.

Worthen, W.B. Shakespeare and the Authority of Performance. Cambridge: CUP, 1996. Print.

Yachnin, Paul, and Jessica Slights, eds. Shakespeare and Character: Theory, History, Performance and Theatrical Persons. Basingstoke: Palgrave, 2009. Print.

\section{NOTES}

${ }^{1}$ The Russian director Konstantin Stanislavsky, whose practice is often elided with naturalism, in fact resisted the term; for him, "[r]ealism in art is the method which helps to select only the typical from life," whereas naturalism occurs only when "[w]e do not know how to separate the main from the secondary, and thus we bury the idea with details of the mode of life" (qtd. in Gordon 45).

${ }^{2}$ See, for example, Barker, "Inner Monologues" and "Freshly Creepy"; Solga, "Realism and the Ethics of Risk."

${ }^{3}$ See especially Carnicke 105-23 and 125-45. Carnicke's work, alongside Jean Benedetti's fresh translations of Stanislavsky, has demonstrated the extent to which misreadings of Stanislavsky's writings have influenced our resistance to his work.

${ }^{4}$ Rosemary Malague's important new An Actress Prepares: Women and "The Method", explores in depth the variations among Strasberg, Adler, Meisner, and Hagen in their work on and with Stanislavsky.

${ }^{5}$ Wilson played Annabella in the 2012 but not the 2013 tour of this production.

${ }^{6}$ In The Actor and the Target, Donnellan suggests how discoveries from his rehearsal process may serve as an important source of the physical objects that ultimately appear in the productions he creates with his designer, partner and collaborator Nick Ormerod. For example, in one memorable instance a Russian actress playing Juliet works in reaction to the shifting 
meanings, memories, and associations provoked by a rehearsal-room chair (129). Cheek by Jowl associate Edward Fortes recalls Annabella's bed as an important rehearsal-room tool, arriving early on and developing in collaboration with actress Lydia Wilson (personal email).

${ }^{7}$ Strindberg conceives the set of his seminal naturalistic tragedy, Miss Julie, as cut on the diagonal in order to create a certain amount of only partly visible space, and encourages his actors to turn their backs to the audience whenever necessary. See Strindberg, "Preface."

${ }^{8}$ Chaudhuri understands Strindberg's spatialization of Miss Julie to work both for and against naturalism: she argues that the play stages naturalism's goals as well as its inherent limitations, imbricating it in the development of a modern, fraught sense of the private as that which can never be known in its entirety. The notion that naturalism is defined by its constant explorations of the paradoxes inherent in the very idea of putting "the real" on a stage is also central to Kirk Williams's exploration of the ethics of the genre.

${ }^{9}$ In particular, consider the Royal Shakespeare Company's productions in 1978 (dir. Ron Daniels) and 1991 (dir. David Leveaux), and the National Theater's production in 1988 (dir. Alan Ayckbourn). 